\title{
PERSEPSI SISWA TENTANG MEDIA PEMBELAJARAN POWER POINT DALAM PEMBELAJARAN FISIKA PADA PESERTA DIDIK KELAS XI MIA 2 SMA NEGERI 9 MAKASSAR
}

\author{
1) Yulia Syahbani, ${ }^{2)}$ Abdul Haris, ${ }^{3)}$ Pariabti Palloan \\ Universitas Negeri Makassar \\ Kampus UNM Parangtambung Jln. Daeng Tata Raya, Makassar, 90224 \\ ${ }^{1)}$ e-mail : yusya@gmail.com
}

\begin{abstract}
Abstrak. Persepsi merupakan suatu pandangan yang muncul pada seseorang terhadap suatu objek atau peristiwa setelah ia mengamatinya. Peneltian ini dilakukan dengan tujuan untuk mengetahui persepsi siswa tentang media pembelajaran power point dalam pembelajaran fisika pada peserta didik kelas XI MIA 2 di SMA Negeri 9 Makassar. Sampel dalam penelitian ini adalah peserta didik kelas XI MIA 2 SMA Negeri Negeri 9 Makassar yang berjumlah 26 peserta didik. Penelitian ini menggunakan pendekatan kualitatif dan kuantitatif dengan metode deskriptif, data-data kuantitaf dalam penelitian ini didapatkan dengan cara penilaian lembar angket dengan menggunakan rumus persentase angket. Hasil penelitian pada persepsi siswa tentang media pembelajaran interaktif melalui power point terhadap pembelajaran fisika dikelas XI MIA 2 SMA Negeri 9 Makassar secara keseluruhan adalah 73, 4 \% sehingga dapat dikategorikan dalam kategori baik.
\end{abstract}

Kata kunci : Persepsi, pembelajaran fisika.

\begin{abstract}
Perception is a view that appears on a person against an object or event after he observes it. This research was conducted with the aim to find out students' perceptions of power point learning media in physics learning for students of class XI MIA 2 in Makassar 9 SMA. The sample in this study were students of class XI MIA 2 Makassar State 9 Senior High School totaling 26 students. This study used a qualitative and quantitative approach with descriptive methods, the quantitative data in this study was obtained by means of a questionnaire sheet by using a percentage questionnaire formula. The results of the study on students' perceptions of interactive learning media through power point towards physics learning in class XI MIA 2 Makassar 9 Public High School as a whole is $73.4 \%$ so that they can be categorized as good.
\end{abstract}

Keywords : Perception, learning physics.

\section{PENDAHULUAN}

Fisika sebagai salah satu mata pelajaran yang memiliki kontribusi besar terhadap perkembangan ilmu pengetahuan dan teknologi saat ini. Oleh karena itu, Fisika seharusnya dapat diperkenalkan kepada masyarakat baik melalui pendidikan formal maupun non formal. Menurut Marwan AR (2016) dalam artikelnya menyatakan bahwa salah satu cabang Ilmu Pengetahuan Alam adalah fisika yang merupakan ilmu yang mempelajari tentang gejala-gejala alam yang juga merangkap ilmu lainnya seperti matematika, kimia dan biologi. Fisika juga membahas tentang kejadian nyata dan abstrak yang harus dibuktikan melalui beberapa percobaan dan pembuktian rumus-rumus. Menurut Marwan AR (2016) dalam artikelnya menyatakan bahwa salah satu cabang Ilmu
Pengetahuan Alam adalah fisika yang merupakan ilmu yang mempelajari tentang gejala-gejala alam yang juga merangkap ilmu lainnya seperti matematika, kimia dan biologi. Fisika juga membahas tentang kejadian nyata dan abstrak yang harus dibuktikan melalui beberapa percobaan dan pembuktian rumus-rumus. Materi yang bersifat abstrak, fisika dianggap sulit dimengerti dan dipahami oleh peserta didik tingkat menengah, sehingga harus menjelaskannya dengan sejelas-jelasnya agar peserta didik dapat memahaminya dengan mudah (Sadiman, dkk 2010: 7). Untuk itu bagi pendidik diharapkan mampu menyesuaikan media apa yang harus digunakan dan sesuai untuk menyesuaikan tujuan dari pembelajaran. Pendidik juga mampu membuat atau merancang media sederhana agar 
peserta didik lebih tertarik untuk mengikuti jalannya proses belajar mengajar.

SMA Negeri 9 Makassar merupakan salah satu sekolah yang menerapkan pembelajaran dengan menggunakan media. Dari hasil wawancara juga diperoleh informasi bahwa pembelajaran fisika di sekolah tersebut telah menggunakan beberapa media dalam pembelajarannya termasuk Microsoft Power Point. Dalam penggunaan media tersebut guru sering membuat ilustrasi gambar yang sesuai dengan materi kedalam media power point agar terlihat lebih nyata dan membuat siswa lebih memahamai makna dari penjelasan dibuku pelajaran. Berdasarkan latar belakang di atas peneliti akan melakukan penelitian dengan judul "persepsi siswa tentang media pembelajaran power point dalam pembelajaran fisika pada peserta didik kelas XIMIA2 SMA Negeri 9 Makassar". Penelitian ini dilaksanakan pada semester ganjil tahun 2018/2019. Tujuan dari penelitian ini adalah untuk mengetahui persepsi siswa tentang media pembelajaran power point dalam pembelajaran fisika pada peserta didik kelas XIMIA2 di SMA Negeri 9 Makassar.

\section{METODE}

Berdasarkan latar belakang yang telah dikemukakan oleh peneliti, maka Penelitian ini menggunakan pendekatan kualitatif dan kuantitatif dengan metode deskriptif, data-data kuantitaf dalam penelitian ini didapatkan dengan cara penilaian lembar angket dengan cara menggunakan rumus persentase angket. Penelitian ini dilaksanakan dikelas XIMIA2 SMA Negeri 9 Makassar, pada semester ganjil tahun 2018/2019.

Prosedur pelaksanaan pada penelitian ini yaitu tahap persiapan, pada tahap ini peneliti terlebih dahulu melakukan observasi ke sekolah SMA Negeri 9 Makassar, kemudian peneliti menjumpai kepala sekolah untuk mendapatkan izin agar dapat melakukan penelitian disekolah tersebut. Selanjutnya, peneliti menentukan sampel penelitian yaitu peserta didik XIMIA2. Menyiapkan instrumen penelitian berupa lembar angket yang digunakan pada saat penelitian. Pernyataan angket terdiri atas 25 butir pernyataan dengan 4 alternatif jawaban, dan melakukan validasi dengan menggunakan pendapat ahli. Kemudian tahap pelaksanaan, pada tahap ini peneliti menyebarkan angket serta melakukan wawancara terhadap sampel. Penyebaran angket dilakukan pada tanggal 4 Agustus 2018 yang dilaksanakan dikelas XIMIA2 dari pukul 12.3014.30 WITA. Kemudian tahap evaluasi, Peneliti mengumpulkan lembar angket yang sudah diisi selama penelitian. Kemudian peneliti mengolah dan menganalisis data angket dengan menggunakan metode yang telah ditentukan. Data angket yang sudah diperoleh dengan metode kuantitatif akan dideskripsikan dengan metode penelitian kualitatif. Kemudian penyusunan laporan, peneliti menyusun hasil pengolahan data dari lembar angket yang telah diisi oleh responden untuk melihat bagaimana persepsi siswa terhadap media pembelajaran interaktif melalui power point terhadap pembelajaran fisika di SMA Negeri 9 Makassar, dan kemudian melaporkan hasil penelitian.

Data yang dikumpulkan dari penelitian ini yaitu data yang berasal dari angket. Kemudian skor tersebut dihitung dengan rumus presentase. Adapun rumusnya seperti yang dikemukakan oleh Sugiono, 2013: 43.

$$
\mathbf{P}=\frac{\mathbf{f}}{\mathbf{N}} \times 100 \%
$$

Keterangan :

$\mathrm{P} \quad=$ Nilai persentase jawaban responden

$\mathrm{f} \quad=$ Frekuensi jawaban responden

$\mathrm{N}$ = Jumlah responden (sampel)

\section{HASIL DAN PEMBAHASAN}

A. Hasil

Dari hasil jawaban responden pada kuesioner, diperoleh data per indikator sebagai berikut: 


\section{Efektifitas media}

Berdasarkan indikator pertama pada kuesioner terdapat 5 pernyataan mengenai efektifitas media pembelajaran, dari ke lima pernyataan tersebut diperoleh data sebagai berikut:

a) Guru menggunakan media pembelajaran dalam mengajar $(+)$

Tabel 1. Penggunaan Media

\begin{tabular}{lcc}
\hline & Frequency & Percent \\
\hline Tidak Setuju & 1 & 3,8 \\
Setuju & 16 & 61,5 \\
Sangat Setuju & 9 & 34,6 \\
& & \\
\hline Total & 26 & 100,0 \\
\hline
\end{tabular}

Berdasarkan data diatas, menunjukkan bahwa dari 26 responden, terdapat 9 responden (34,6\%) menjawab sangat setuju, 16 responden (61,5\%) menjawab setuju, 1 responden $(3,8 \%)$ menjawab tidak setuju.

b) Guru menggunakan media pembelajaran power point yang bervariasi $(+)$

Tabel 2. Pengunaan Media Bervariasi

\begin{tabular}{lcc}
\hline & Frequency & Percent \\
\hline Tidak Setuju & 3 & 11,5 \\
Setuju & 9 & 34,6 \\
Sangat & 14 & 53,8 \\
Setuju & & \\
\hline Total & 26 & 100,0 \\
\hline
\end{tabular}

Berdasarkan data diatas, menunjukkan bahwa dari 26 responden, terdapat 14 responden (53,8 \%) menjawab sangat setuju, 9 responden (34,6\%) menjawab setuju, 3 responden (11,5\%) menjawab tidak setuju.

c) Guru menggunakan media pembelajaran power point selain buku $(+)$

Tabel 3. media power point selain buku

\begin{tabular}{lcc}
\hline & Frequency & Percent \\
\hline Tidak Setuju & 4 & 15,4 \\
Setuju & 9 & 34,6 \\
Sangat Setuju & 13 & 50,0 \\
& & \\
\hline Total & 26 & 100,0 \\
\hline
\end{tabular}

Berdasarkan data diatas, menunjukkan bahwa dari 26 responden, terdapat 13 responden (50,0 \%) menjawab sangat setuju, 9 responden $(34,6 \%)$ menjawab setuju, 4 responden $(15,4 \%)$ menjawab tidak setuju. Hasil penelitian menunjukkan bahwa dalam pembelajaran fisika, guru dapat menggunakan media pembelajaran power point selain buku.

d) Dalam mengajar guru menggunakan media pembelajaran power point yang kreatif $(+)$

Tabel 4. Penggunaan Media Dalam Mengajar

\begin{tabular}{lcc}
\hline & Frequency & Percent \\
\hline Setuju & 13 & 50,0 \\
$\begin{array}{l}\text { Sangat } \\
\text { Setuju }\end{array}$ & 13 & 50,0 \\
\hline Total & 26 & 100,0 \\
\hline \multicolumn{1}{c}{ Berdasarkan } & data diatas, & menunjukk
\end{tabular}

Berdasarkan data diatas, menunjukkan bahwa dari 26 responden, terdapat 13 responden $(50,0 \%)$ menjawab sangat setuju, 13 responden $(50,0 \%)$ menjawab setuju.

e) Guru menggunakan media pembelajaran power point yang tidak sesuai dengan materi pembelajaran (-)

Tabel 5. Penggunaan Media Power Point Sesuai Materi

\begin{tabular}{lcc}
\hline & Frequency & Percent \\
\hline Sangat Setuju & 2 & 7,7 \\
Setuju & 3 & 11,5 \\
Tidak Setuju & 13 & 50,0 \\
Sangat Tidak & 8 & 30,8 \\
Setuju & & \\
\hline Total & 26 & 100,0 \\
\hline
\end{tabular}

Berdasarkan data diatas, menunjukkan bahwa dari 26 responden, terdapat 2 responden $(7,7 \%)$ menjawab sangat setuju, 3 responden $(11,5 \%)$ menjawab setuju, 13 responden $(50,0 \%)$ menjawab tidak setuju, dan 8 responden $(30,8 \%)$ menjawab sangat tidak setuju. 


\section{Sikap siswa terhadap penggunaan media}

Berdasarkan indikator kedua pada kuesioner terdapat 6 pernyataan mengenai sikap siswa terhadap penggunaan media, dari keenam pernyataan tersebut diperoleh data sebagai berikut:

a) Siswa lebih mudah memahami pelajaran setelah guru menggunakan media pembelajaran power point $(+)$

Tabel 6. Mudah Memahami Pelajaran Saat Menggunakan Media

\begin{tabular}{lcc}
\hline & Frequency & Percent \\
\hline Tidak Setuju & 3 & 11,5 \\
\hline Setuju & 14 & 53,8 \\
\hline Sangat Setuju & 9 & 34,6 \\
\hline Total & 26 & 100,0 \\
\hline
\end{tabular}

Berdasarkan data diatas, menunjukkan bahwa dari 26 responden, terdapat 9 responden $(34,6 \%)$ menjawab sangat setuju, 14 responden $(53,8 \%)$ menjawab setuju, 3 responden $(11,5 \%)$ menjawab tidak setuju.

b) Siswa merasa bosan jika kegiatan mengajar tidak menggunakan media pembelajaran power point $(+)$

Tabel merasa bosan ketika tidak menggunakan media

\begin{tabular}{|l|c|c|}
\hline & Frequency & Percent \\
\hline Tidak Setuju & 8 & 30,8 \\
\hline Setuju & 14 & 53,8 \\
\hline $\begin{array}{l}\text { Sangat } \\
\text { Setuju }\end{array}$ & 4 & 15,4 \\
\hline
\end{tabular}

\section{B. Pembahasan}

Berdasarkan hasil wawancara terhadap guru tentang media pembelajaran interaktif yaitu sangat berpengaruh terhadap efektifitas media saat guru mengajar, motivasi belajar sisiwa yang lebiih meningkat, frekuensi penggunaan media pembelajaran yang diminati, aktivitas belajar fisika pada siswa lebih aktif dan manfaat pembelajaran yang lebih terlihat. Hasil wawancara terhadap sisiwa tentang media pembelajaran power point yaitu lebih mudah memahami maksud dari materi pembelajaran yang diberikan oleh guru serta lebih bersemangat dalam mengikuti proses belajar mengjajar. Berdasarkan hasil penelitian pada masing-masing pendapat atau persepsi siswa tentang media pembelajaran interaktif melalui power point di SMA Negeri 9 Makassar, dengan 4 alternatif jawaban yaitu sangat setuju (SS), setuju (S), tidak setuju (TS), dan sangat tidak setuju (STS), keempat alternative jawaban tersebut memberikan jawaban terhadap berbagai persepsi siswa yang menunjukkan bahwa sebagian besar siswa di SMA Negeri 9 Makassar khususnya kelas XIMIA2 berpendapat bahwa belajar fisika melalui media interaktif power point lebih menyenangkan.

Hal ini juga didukung oleh hasil penelitian yang dilakukan oleh Idruz (2010) yang menunjukkan bahwa belajar fisika melalui media power point lebih menyenangkan. Dari hasil penelitian menunjukkan bahwa terdapat nilai positif antara persepsi siswa tentang penggunaan media pembelajaran power point dalam pembelajaran fisika. Pemilihan media yang tepat dalam pembelajaran sangatlah mempengaruhi hasil belajar. Selain itu, media yang digunakan dalam pembelajaran haruslah sesuai dengan materi yang diajarkan. Sehingga, selain harus mampu menggunakan media, pendidik juga dituntut untuk memahami media pembelajaran power point yang akan digunakan.

\section{SIMPULAN}

Berdasarkan hasil pembahasan pada bab sebelumnya, tentang persepsi siswa tentang media pembelajaran power point di SMA Negeri 9 Makassar, dapat ditarik sebuah kesimpulan bahwa persepsi siswa tentang media pembelajaran interaktif melalui power point dalam pembelajaran fisika kelas $\mathrm{XI}_{\mathrm{MIA} 2}$ SMA Negeri 9 Makasar secara keseluruhan adalah 73, 4 \% 


\section{DAFTAR RUJUKAN}

Arief S. Sadiman, ddk. 2010. Media Pendidikan. Jakarta: Raja Grafindo Persada.

Marwan AR. 2016 Ilmu Pengetahuan Alam Fisika. Jakarta: Rineka Cipta.

Sugiono. 2013. Metode Penelitian Kombinasi. Bandung: Alfabeta.

Syabani, Yulia. 2018. Persepsi Siswa Tentang Media Pembelajaran Power Point
Dalam Pembelajaran Fisika Pada Peserta Didik Kelas Ximia2 Sma Negeri 9 Makassar. Makassar: UNM.

Idruz. 2010. Persepsi siswa tentang penggunaan media power point dalam belajar fisika di Sma Neg 8. Makassar. Makassar: UNM 